\title{
Evaluation of Melon Seed Oil Citrullus Colocynthis (L.) Schrad, for the Protection of Cowpea Vigna Unguiculata Seeds against Callosobruchus Maculatus (Fabricius) (Coleoptera: Bruchidae)
}

\author{
Chukwunonso O. Nzelu ${ }^{1}$, Nnaemeka J. Okonkwo ${ }^{2}$ \\ Department of Parasitology and Entomology, Nnamdi Azikiwe University, Awka, Anambra State, Nigeria ${ }^{1,2}$ \\ Department of Crop Science and Horticulture, Nnamdi Azikiwe University, Awka, Anambra State, Nigeria ${ }^{2}$
}

\begin{abstract}
Citrullus colocynthis (L.) Schrad seeds generally called Egusi melon are widely eaten in Nigeria, but its uses in post-harvest crop protection have not been exploited. The effects of the edible oil of C. colocynthis seeds on Callosobruchus maculatus (F.) were assessed on adult mortality, oviposition, $F_{1}$ progeny emergence, cowpea seed damage and seed germinability in the laboratory. Results indicated that the oil showed some lethal effects on treated insects at above 50\% mortality and very high reduction in oviposition at increased concentrations. Seeds treated with the oil showed significant $(\mathrm{P}<0.05)$ reduction in the number of progeny of $\mathrm{C}$. maculatus. There was no observable feeding damage on seeds treated with the highest concentration of the oil applied. In addition, the oil has no adverse effect on seed viability. The present studies indicate that the application of the oil show promise in post-harvest protection of cowpea seeds.
\end{abstract}

Key words: Citrullus colocynthis seed oil, cowpea seed protection; Callosobruchus maculatus.

\section{INTRODUCTION}

Cowpea Vigna unguiculata Linnaeus (Walpers) is one of the foremost leguminous crops cultivated in Africa. Though native to West Africa, the crop occupies a prominent place in the diet of many Nigerians because of the edible seeds and cheap source of protein.

Post harvest losses due to storage insect pests have been recognized as an increasing constraint in Africa with losses averaging $30 \%$ of grain dry weight in stored maize due to a complex of insect pests [1]. Callosobruchus maculatus (Fabricius) (Coleoptera: Bruchidae) is a cosmopolitan insect pest of cowpea. The insect is a fieldto-store pest as its infestation of cowpea often begins in the field while the mature pods dry [2]. It multiplies very rapidly in storage where it causes very high losses [3]. C. maculatus damage to cowpea seeds may reach $50 \%$ after six months of storage [4]. The insect consumes $50-90 \%$ of cowpea in storage annually throughout tropical Africa [5], thus affecting seed quality, market value and seed viability after 3 months of storage [6].

Although the success of any control program depends ultimately upon a combination of methods, the most efficient and dependable single means of control has been that of the use of synthetic insecticides [7]. The cost of chemical insecticides has tremendously increased to become prohibitive to small-scale farmers.
However, the problems associated with chemical insecticides such as health hazards, insect resistance, pest resurgence, residual toxicity and widespread environmental hazards have made it imperative to use biodegradable pesticides [8-9]. Most pesticidal plants also have medicinal values and some are consumed by humans as spices [10-11]. Furthermore, there is also growing interest in entomological research to identify and evaluate plant materials with insecticidal properties for control of various insect pests, including C. maculatus [12-17].

Citrullus colocynthis (L.) Schrad commonly called egusi melon is widely cultivated in Nigeria. It is oil seed of high oil content about $50-53 \%$ oil, $28 \%$ protein and other important mineral nutrients [18-19]. Its seeds are used in preparing egusi soup, relish, melon ball snacks and other fermented condiments. The seeds are rich in high quality oil [20]. The oil contains a fairly high amount of unsaturated fatty acid, linoleic acid. The economic and industrial uses of $\mathrm{C}$. colocynthis seeds have long been known, however, the insecticidal application have not yet been exploited. There is a dearth of information in the literature on the application of $\mathrm{C}$. colocynthis seed oils as grain/seed protectant against stored products insects. The present studies therefore were designed to evaluate the efficiency of the oil in the control of cowpea beetle in store. 


\section{MATERIALS AND METHODS}

\section{A. Insect culture}

Cowpea seeds were purchased from the Eke market in Awka, Anambra state, Nigeria and taken to the laboratory. The infested seeds were placed in a plastic container and covered with muslin cloth held in place with rubber bands in order to allow sufficient air into the jar, till the emergence of adult. Emerged adults of both sexes were transferred into another plastic container containing sterilized clean cowpea seeds and maintained at $28 \pm 2{ }^{\circ} \mathrm{C}$ and $60 \pm 5 \%$ R.H. and $12 \mathrm{~h}: 12 \mathrm{~h}$ light : dark regime as culture for subsequent use. The culture was kept undisturbed to produce enough progeny used for the experiments.

\section{B. Preparation and extraction of melon oil}

The Egusi melon seeds were purchased from Eke market in Awka, Anambra state, Nigeria. The dried dehusked seeds were ground into fine powder using pestle and mortar. The oil was extracted manually by forming dough with pastes and gradually pressed the dough while adding little quantity of distilled water. The oil extracted was stored in air-tight bottle after heating on low flame to expel any water and kept at room temperature. This served as stock solution.

\section{Bioassay}

Experimental cowpea seeds were properly sieved to remove any debris and dust particles and handpicked to remove plants remains, foreign and damaged seeds. They were sterilized in electric oven at $50^{\circ} \mathrm{C}$ for $6 \mathrm{hrs}$ in order to kill all eggs and developing larvae of cowpea bruchids. All bioassay tests were carried out under ambient in the laboratory, the same conditions as the insect culture; $28 \pm$ $2{ }^{\circ} \mathrm{C}$ and $60 \pm 5 \%$ R.H. and $12 \mathrm{~h}$ : $12 \mathrm{~h}$ light: dark regime.

D. Effect of melon seed oil on bruchid mortality

Twenty grammes $(20 \mathrm{~g})$ of the cowpea sample were weighed separately into separate sterilized $100 \mathrm{ml}$ plastic vials. Serial dilution containing 200, 400, 600, 800 and $1000 \mu \mathrm{l}$ of the oil in acetone (Analar grade) were then prepared in $20 \mathrm{ml}$ syringe stored for subsequent treatments. The treated seeds were vigorously shaken to ensure proper dispersal coating of the seeds. Controls without oil treatment were included. The vials together with treated samples were kept for one hr with the lid left open to allow the acetone evaporate completely. Subsequently, twenty of 1 day old adults of both sexes were introduced into each vial treated seeds. The lids were finally covered with a muslin cloth to allow aeration and prevent exist or entry of insects. Each treatment level was replicated four (4) times. The experiment was arranged in a completely randomized design (CRD) and kept on the laboratory bench for observation ( 3 days). The number of dead insects in each vial was counted daily for $72 \mathrm{hrs}$.

The bruchid mortality was determined by:

Number of dead insects x $100=\%$ mortality

Total number of insects
The data collected on insect mortality were further subjected to analysis of variance.

E. Effects of the oil extract on oviposition

At the end of the mortality record, all insects were removed. The number of eggs laid on treated seeds (Ts) and control seeds (Cs) were recorded and subjected to statistical analysis.

F. Effects of melon seed oil extract on $\mathrm{F}_{1}$ adult emergence After the egg count, the experimental set up was left undisturbed till the emergence of $F_{1}$ adults from day 30 post treatment. The number of $F_{1}$ adults from the control (AC) and treated seeds (At) were recorded.

The percentage reduction in $\mathrm{F} 1$ progeny (PR) was calculated as follows:

$$
\mathrm{PR}=[(\mathrm{Ac}-\mathrm{At}) / \mathrm{Ac}] \mathrm{X} 100 .
$$

G. Assessment of seed damage

The number of damaged cowpea seeds (seeds with characteristic holes) in both treated and untreated sample vials and undamaged grains were counted. The number of damaged seeds was expressed as a percentage of the total number of seeds in each vial.

\section{H. Seed germination test after treatment}

Viability of the treated seeds was carried out at the end of experiment using sterile Petri dishes containing $9 \mathrm{~cm}$ Whatman No. 1 filter paper. Ten seeds from each treatment were randomly selected from each vial for germination test. The seeds were moistened daily $(10 \mathrm{ml}$ of distilled water). The set-up was exposed to light on the laboratory bench. The number of seeds that germinated was recorded after four days. The percentage germination was subsequently determined and subjected to statistical analysis.

\section{Statistical analysis}

For the toxicity test, data obtained were transformed to percentage. Abbot's formula [21] was used to adjust for deaths in control treatment, and subsequently subjected to analysis of variance (ANOVA). All data obtained from other parameters were also subjected to ANOVA. Furthermore, the significant difference between the means was separated using the Least Significant Difference (LSD).

\section{RESULTS}

A. Adult beetle mortality

The bioactivity of $\mathrm{C}$. colocynthis oil is shown in Table I. There was dose-dependent mortality response in the observed data. All concentration levels with the oil showed some level of mortality response with the highest dose $(1000 \mu \mathrm{l} / 20 \mathrm{~g}$ or $5.0 \%$ treatment $)$ giving $97 \%$ mortality of the bruchids after 3 days post-treatment. All rates of application of C. colocynthis oil significantly caused higher mortality of $\mathrm{C}$. maculatus adult than the control. 
From this study, it was observed that bruchid mortality treatments. There were no progeny produced in seeds increased with increasing application dosage of the oil treated with the highest (5.0\%) dose, however not treatments.

Table I Mean $( \pm$ SE) percent adult mortality of $C$. maculatus after 72 hours exposure to $C$. colocynthis seed oil on treated seeds

\begin{tabular}{cc}
\hline $\begin{array}{c}\text { Treatment } \\
\text { (concentration \%) }\end{array}$ & $\begin{array}{c}\text { Mean \% mortality } \\
( \pm \text { SE) }\end{array}$ \\
\hline Control $(0.0 \%)$ & $5.53 \pm 2.77 \mathrm{a}$ \\
\hline $200 \mu \mathrm{l}(1.0 \%)$ & $31.93 \pm 12.36 \mathrm{~b}$ \\
\hline $400 \mu \mathrm{l}(2.0 \%)$ & $41.67 \pm 10.50 \mathrm{bc}$ \\
\hline $600 \mu \mathrm{l}(3.0 \%)$ & $50.00 \pm 8.69 \mathrm{bcd}$ \\
\hline $800 \mu \mathrm{l}(4.0 \%)$ & $56.87 \pm 10.81 \mathrm{bcde}$ \\
\hline $1000 \mu \mathrm{l}(5.0 \%)$ & $97.20 \pm 1.40 \mathrm{f}$ \\
\hline $\operatorname{LSD}_{(0.05)}$ & 27.19 \\
\hline
\end{tabular}

Means ( \pm se) followed by the same alphabet are not significantly different $(\mathrm{P}>0.05)$. SE; standard error.

B. Effect of the oil on oviposition of C. maculatus are presented in Table II

There were significant $(\mathrm{P}<0.05)$ reduction in oviposition among the different level of treatments compared with the control $53.0 \pm 7.6 \mathrm{eggs} / 20 \mathrm{~g}$ of seeds (Table II). The highest number of eggs $53.0 \pm 7.6$ was laid by $\mathrm{C}$. maculatus on the $20 \mathrm{~g}$ seeds in the control. The least number of eggs $2.43 \pm 0.28$ were laid on cowpea seeds treated with $1000 \mu \mathrm{l}(5.0 \%) / 20 \mathrm{~g}$ oil which were not significantly $(\mathrm{P}>0.05)$ different from the oviposition on the seeds treated with $600 \mu \mathrm{l}(3.0 \%)$ and $800 \mu \mathrm{l}(4.0 \%) \mathrm{C}$. colocynthis oil.

Table II Oviposition deterrent activity of C. colocynthis seed oil extracts against C. maculatus

\begin{tabular}{ccc}
\hline $\begin{array}{l}\text { Treatment } \\
(\text { conc. \%) }\end{array}$ & $\begin{array}{l}\text { Mean no. of } \\
\text { C. maculatus } \\
( \pm \text { SE })\end{array}$ & $\begin{array}{l}\% \\
\text { Reduction in } \\
\text { oviposition }\end{array}$ \\
\hline Control $(0.0 \%)$ & $53.00 \pm 7.60 \mathrm{a}$ & - \\
\hline $200 \mu 1(1.0 \%)$ & $27.65 \pm 6.53 \mathrm{~b}$ & 47.83 \\
\hline $400 \mu 1(2.0 \%)$ & $17.33 \pm 3.95 \mathrm{bc}$ & 67.31 \\
\hline $600 \mu 1(3.0 \%)$ & $10.35 \pm 2.06 \mathrm{~cd}$ & 80.47 \\
\hline $800 \mu 1(4.0 \%)$ & $5.58 \pm 1.29 \mathrm{cde}$ & 89.15 \\
\hline $1000 \mu 1(5.0 \%)$ & $2.43 \pm 0.28 \mathrm{de}$ & 95.42 \\
\hline $\operatorname{LSD}_{(0.05)}$ & 13.40 & \\
\hline
\end{tabular}

Means ( \pm s.e) followed by the same alphabet are not significantly different $(\mathrm{P}>0.05)$.

C. Effects of the oil extracts on $F_{1}$ progeny production are shown in Table III

The number of progeny produced by $\mathrm{C}$. maculatus in untreated seeds and those treated with different concentrations of the oil were significantly $(\mathrm{P}<0.05)$ different. The $F_{1}$ adult emergence from the control treatment was significantly $(\mathrm{P}<0.05)$ higher than the other significantly different $(\mathrm{P}>0.05)$ from the $\mathrm{F}_{1}$ production on the $800 \mu 1(4.0 \%)$ oil treatment. The $1.0 \%$ and $2.0 \%$ oil treatments though produced varying effects on oviposition but these were not significantly $(\mathrm{P}>0.05)$ different.

D. Effect on seed damage are also shown in Table III There were significant $(\mathrm{P}<0.05)$ differences in the reduction of seed damage by the insect at different levels of oil treatment compared with the control. There was no damage recorded in the cowpea seeds treated with $1000 \mu \mathrm{l}$ $(5.0 \%)$ of C. colocynthis oil, however, not significantly (P>0.05) different from seeds treated with $800 \mu 1(4.0 \%)$ of the oil. The level of damage $(9.025 \pm 0.82)$ in the control treatment was significantly $(\mathrm{P}<0.05)$ higher than all the other treatments.

Table III Production of $\mathrm{F}_{1}$ progeny and seed damage by $\mathrm{C}$. maculatus on treated seeds

\begin{tabular}{lcl}
\hline $\begin{array}{l}\text { Treatment } \\
\text { conc. \%) }\end{array}$ & $\begin{array}{c}\text { Mean no. of } \mathrm{F}_{1} \\
\text { progeny }( \pm \mathrm{SE})\end{array}$ & $\begin{array}{l}\text { Mean } \\
\% \text { damage } \\
( \pm \mathrm{SE})\end{array}$ \\
\hline Control $(0.0 \%)$ & $19.50 \pm 1.71 \mathrm{a}$ & $9.03 \pm 0.82 \mathrm{a}$ \\
\hline $200 \mu \mathrm{l}(1.0 \%)$ & $10.50 \pm 1.19 \mathrm{~b}$ & $4.58 \pm 0.63 \mathrm{~b}$ \\
\hline $400 \mu \mathrm{l}(2.0 \%)$ & $8.00 \pm 1.29 \mathrm{bc}$ & $3.98 \pm 0.28 \mathrm{bc}$ \\
\hline $600 \mu \mathrm{l}(3.0 \%)$ & $4.75 \pm 1.70 \mathrm{~cd}$ & $2.43 \pm 0.86 \mathrm{~cd}$ \\
\hline $800 \mu \mathrm{l}(4.0 \%)$ & $0.50 \pm 0.50 \mathrm{e}$ & $0.60 \pm 0.30 \mathrm{e}$ \\
\hline $1000 \mu \mathrm{l}(5.0 \%)$ & $0.00 \pm 0.00 \mathrm{e}$ & $0.00 \pm 0.00 \mathrm{e}$ \\
\hline $\mathrm{LSD}_{(0.05)}$ & 3.67 & 1.70 \\
\hline
\end{tabular}

Means ( \pm s.e) followed by the same alphabet are not significantly different $(\mathrm{P}>0.05)$.

\section{E. Effect on seed germination}

There was no adverse effect of the oil on seed viability compared with the control treatment (Table IV). A hundred percent seed germination was recorded in both $4.0 \%$ and $5.0 \%$ treatment levels. There was $75 \%$ germination in the $3.0 \%$ oil treatment and at both $1.0 \%$ and $2.0 \%$ treatment levels, $50 \%$ germination was achieved.

Table IV Effect of Citrullus colocynthis seed oil on germination of cowpea seeds

\begin{tabular}{cc}
\hline $\begin{array}{c}\text { Treatment } \\
\text { conc. } \%)\end{array}$ & $\begin{array}{c}\text { Mean \% germination } \\
( \pm \mathrm{SE})\end{array}$ \\
\hline Control $(0.0 \%)$ & $12.5 \pm 4.80 \mathrm{a}$ \\
\hline $200 \mu 1(1.0 \%)$ & $50.0 \pm 4.10 \mathrm{~b}$ \\
\hline $400 \mu 1(2.0 \%)$ & $50.0 \pm 4.10 \mathrm{bc}$ \\
\hline $600 \mu 1(3.0 \%)$ & $75.0 \pm 6.50 \mathrm{~d}$ \\
\hline $800 \mu 1(4.0 \%)$ & $100 \pm 0.0 \mathrm{e}$ \\
\hline $1000 \mu 1(5.0 \%)$ & $100 \pm 0.0 \mathrm{e}$ \\
\hline $\operatorname{LSD}_{(0.05)}$ & 12.0 \\
\hline
\end{tabular}

Means ( \pm s.e) followed by the same alphabets are not significantly different $(\mathrm{P}>0.05)$. 


\section{DISCUSSION}

Essential oils are commonly used in insect control because they are relatively efficacious against virtually all life stages of insects [22]. It has been reported that plant oils contained monoterpenes such as 1,8-cineole, eugenol and camphor that can elicit mortality and inhibition of progeny production [23]. In this study, the essential oil of the seeds of C. colocynthis had significant toxic effect to the cowpea bruchid. The mortality increased as the concentration of oil increased. The highest dose recorded $75 \%$ mortality when compared to the lower dosage rates. This could be as a result of physical discomfort to the bruchid when in direct contact as evidenced by staggering, motionlessness (even after gentle touch with a pin) and interference with normal respiratory activity by blockage of spiracles of the bruchids, resulting in asphyxiation and subsequent death. Essential oils of plant origin are highly lipophilic and therefore, have the ability to penetrate and cause physical abrasion of the insect cuticle (with consequent loss of body fluid). This may be another reason for the potency of the oil extracts. Furthermore, the presence of highly pungent phenolic secondary metabolites or other compounds such as alkaloids, high fatty acid and linoleic acid may play a role with respect to its potency against insects. Thus, the present studies demonstrate that $\mathrm{C}$. colocynthis oil has similar effects as other essential oils such as Ocimum kenyense, Azadirachta indica, Jatropha curcas [23-27] on this post-harvest pest and provides a scientific basis for their use in traditional post-harvest practices.

The high significant reduction in oviposition increased with the increase in dosage of each treatment. Present study revealed that, maximum oviposition deterrent activity occurred at higher concentrations of the seed oil when compared with lower concentration, thereby lowering the egg laying tendency of the pest insect. However, it is noteworthy that this essential oil showed high deterrent activity even at low concentrations. This significant oviposition deterrent principle exhibited by the oil extract in $\mathrm{C}$. maculatus may be due to the changes induced in physiology and behaviour of the adult insect as reflected by their egg laying capacity. Similar results were also obtained from Rhazya stricta leaves, neem seeds, Heliotropium bacciferum aerial parts and citrus peels [9], Jatropha curcas [27], and Zanthoxylum xanthoxyloides [28] against C. maculatus.

In this study, the essential oil had significant effect on the emergence of $\mathrm{C}$. maculatus. The highest aqueous extract dose recorded $100 \%$ reduction in adult emergence. The reduction in the number of $F_{1}$ progeny produced by $C$. maculatus suggests the presence of ovicidal properties in the seeds of C. colocynthis and it could be as a result of eggs of C. maculatus were brought in closer contact with toxic secondary metabolites in C. colocynthis thus causing higher egg mortality that inhibited adult emergence so greatly in treated seeds than control seeds. Other studies have shown that botanicals inhibited $F_{1}$ progeny production and adult emergence of C. maculatus in cowpea [13, 29-32]. These studies further suggested that when eggs are laid on treated seeds, the toxic substance present in the extract may enter into the egg through chorion and suppressed further embryonic development, which are in general agreement with our present findings.

C. colocynthis seed oil offers a high significant protection to cowpea seeds since there was reduction in seed damage as the concentration increased. At the highest dose of seed oil there was $100 \%$ protection of cowpea seeds from damage by C. maculatus. The present study revealed that C. colocynthis seed oil had no adverse effect on seed viability and germination even at higher concentration. With over $80 \%$ germination of cowpea seeds recorded; C. colocynthis did not impaired grain or seed germination and quality.

\section{CONCLUSION}

The rich potentials of Nigerian traditional plants in the management of stored-products insect pests cannot be over-emphasized. The present investigation has demonstrated the efficacy of C. colocynthis against $\mathrm{C}$. maculatus. Preparation of this aqueous oil extract is so easy and application on the seeds for storage is inexpensive and effective. Hence, the results obtained from the present study indicate the enormous potential of C. colocynthis in storage insect pest management systems. Its adoption for use as grain protectant may provide suitable alternative to synthetic insecticides for small-scale farmers and avert the reoccurrence of food poisoning from seeds stored with synthetic insecticides. It is recommended that further studies be conducted to evaluate the bioactive compounds present in the plant oil.

\section{ACKNOWLEDGEMENT}

We thank Dr. E. N. Nwofia and Rev. Dr. K. C. Emeasor, Michael Opara University of Agriculture, Umudike, Abia state, Nigeria for their contribution towards the success of this work. We are indebted to Mr. H Etega for the statistical analysis.

\section{REFERENCES}

[1] IITA, International Institute of Tropical Agriculture. Plant Health Management Division. Annual Report. pp. 43, 1995

[2] V. Sathyaseelan, V. Baskaran, and S. Mohan, "Efficacy of some indigenous pesticidal plants against pulse beetle, Callosobruchus chinensis (L.) on green gram," J. of Entomol. vol. 5, pp. 128-132, 2008.

[3] A. P., Ouedraogo, S. Sou, A. Sanon, J. P. Monge, J. Huignard, B. Tran, and P. F. Crdland, "Influence of temperature and humidity on population of Callosobruchus maculatus (Coleoptera: Bruchidae) and its parasitoid Dinarmus basalis (Pteromalidae) in two climatic zones of Burkina Faso,” Bull. Entomol. Res. vol. 86: pp. 695-702, 1996.

[4] G. H. Caswell, "A review of the work done in the entomology section. Institute of Agricultural Research," Pests of stored grains. Samaru Miscellan, vol. 99: pp 12, 1980.

[5] IITA, International Institute of Tropical Agriculture, Annual Report 1988/89. Ibadan, Nigeria, 1989. 
[6] T. I. Ofuya, and P. F. Credland, "Response of three populations of the seed beetle, Callosobruchus maculatus F. (Coleptera: Bruchid) to seed resistance selected of Cowpea, Vigna unguiculata (L) Walp," J. Stored Prod. Res. vol. 31, pp. 17-27, 1995.

[7] D. A. Adabie-Gomez, K. G. Monford, A. Agyir- Yawson, A. Owusu-Biney, and M. Osae, "Evaluation of four local plant species for insecticidal activity against Sitophilus zeamais Motsch. (Coleoptera :Curculionidae) and Callosobruchus maculatus (F) (Coleoptera: Bruchidae)," Ghana J. Agric. Sci. vol. 39, pp. 147154,2006

[8] F. A. Talukder, and P. E. Howse, "Isolation of secondary plant compound from Aphanamixis polystachya as feeding deterrents against adults Tribolium castaneum (Coleoptera: Tenebrionidae)". J. of Stored Prod. Res. vol. 107, pp. 395-402, 2000.

[9] E. A. Elhag, "Deterrent effects of some botanical products on oviposition of the cowpea bruchid, Callosobruchus maculatus (F.) (Coleoptera: Bruchidae)," Int. J. of Pest Manag. vol. 46, pp. 109$113,2000$.

[10] N. E. S. Lale, "A laboratory study of the comparative toxicity of products from three spices to the maize weevil," Postharvest Biol. Technol. vol. 2, 61-64, 1992.

[11] E. O. Okonkwo, and W. I. Okoye, "The efficacy of four seed powders and the essential oils as protectants of cowpea and maize grains against infestation by Callosobruchus maculatus (Fabricius) (Coleoptera: Bruchidae) and Sitophilus zeamais (Motschulsky) (Coleoptera: Curculionidae) in Nigeria," Int. J. Pest Manage. vol. 42: pp. 143-146, 1996.

[12] E. O. Owusu, "Effect of some Ghanaian plant components on control of two stored-product insect pest of cereals," J. of Stored Prod. Res. vol. 37, pp. 85-91. 2001.

[13] L. A. Tapondjou, C. adler, H. Bouda, and D. A. Fontem, "Efficacy of powder and essential oil from Chenopodium ambrosioides leaves as postharvest grain protectants against six stored product beetles," J. of Stored Prod. Res. vol. 38, pp. 395-402, 2002.

[14] S. J. Boeke, I. R. Baumgart, Loon, J. J. A. A. van Huis, M. Dicke, and D. K. Kossou, "Toxicity and repellency of African plants traditionally used for the protection of stored cowpea against Callosobruchus maculates," J. of Stored Prod. Res. vol. 40, pp. 423-438, 2004.

[15] C. A. Akob, and F. K. Ewete, "The efficacy of ashes of four locally used plant materials against Sitophilus zeamais (Coleoptera: Curculionidae) in Cameroon," Int. J. of Trop. Insect Sci. vol. 40, pp. 21-26. 2007.

[16] O. O. Odeyemi, P. Masika, and A. J. Afolayan "Insecticidal activities of essential oil from the leaves of Mentha longifolia L. subsp. capensis against Sitophilus zeamais (Motschulsky) (Coleoptera: Curculionidae),". African Entomol. vol. 16, pp. 220225, 2008.

[17] M. Jayakumar, "Oviposition deterrent and adult emergence activities of some plant aqueous extracts against Callosobruchus maculatus F. (Coleoptera: Bruchidae)," J. of Biopesticides. vol. 3, pp. 325-329, 2010

[18] E. O. Ekumankama, J. C. Umezuegbu, and O. D. Onukwuli, "Stability studies and prediction of shelf-life of ground seeds of colocynthis vulgaris and Irvingia gabonensis," J. Sci. Engr. Tech. vol. 5, pp. 1187-1201, 1998

[19] F. O. Anuebunwa, "A bio-economic on-farm evaluation of the use of sweet potato for complementary weed control in a yam/maize/egusi/cassava intercrop in pigeon pea hedgerows in the rain forest belt of Nigeria," Biol Agric Hort., vol. 18, pp. 95-102, 2000

[20] M. I. Uguru, "Vegetable crops," Crop production: Tools, Techniques and Practice. Fulladu Pub. Loy. Nsukka, Nigeria. pp. 126-135. 1996

[21] W. S. Abbott, "A Method of Computing the effectiveness of an Insecticide," J. Econ. Entomol., vol. 18, pp. 265-267, 1925.

[22] C. O. Adedire, "Use of nutmeg Myristica fragrans (Houtt.) powder and oil for the control of cowpea storage bruchid, Callosobruchus maculatus Fabricius," J. Plant Dis. Plant Prot. vol. 109, pp. 193199, 2002.

[23] D. Obeng-Ofori, C. H. Reichmuth, J. Bekele, and A. Hassanali, "Biological activity of 1,8-cineole, a major component of essential oil of Ocimum kenyense (Ayobangira) against stored product beetles,” J. Appl. Entomol. vol. 121, pp. 237-243, 1997.
[24] D. K. Weaver, F. V. Dunkel, L. Ntezurubanza, L. L. Jackson, and D. T. Stock, "The efficacy of Linalool, a major component of freshly milled Ocimum canum Sims (Lamiaceae), for protection against post harvest damage by certain stored product Coleoptera," J. Stored Prod. Res. vol. 27: pp. 213-220, 1991.

[25] N. E. S. Lale, and Y. T. Maina, "Influence of carrier solvent on the efficacy of neem (Azadirachta indica A. Juss) seed oil applied for the control of Callosobruchus maculatus (F.) (Coleoptera: Bruchidae)," J. of Plant Dis. and Prot. vol. 110, pp. 492-49, 2003.

[26] C. O. Okunola, and T. I. Ofuya, "Effect of some essential plant oils on insect infestation of stored mazie and cowpea," African crop sci. conf. proceedings.vol. 8: pp. 1003-1007. 2007

[27] B. A. Boateng, and F. Kusi, "Toxicity of Jatropha seed oil to Callosobruchus maculatus (Coleoptera: Bruchidae) and its parasitoid, Dinarmus basalis (Hymenoptera: Pteromalidae)". J. of Appl. Sci. Res., vol. 4, pp. 945-951, 2008.

[28] E. O. Owusu, W. K. Osafo, and E. R. Nutsukpui, "Bioactivities of Candlewood, Zanthoxylum xanthoxyloides (lam.) solvent extracts against two stored-product insect pests," African J. of Sci. and Technol. vol. 89, pp. 17-21, 2007.

[29] K. Govindan, and N. S. Jeyarajan, "Effect of ten plant powders on mortality, oviposition, adult emergence and seed weight loss on pulse beetle, Callosobruchus maculatus (F.) (Coleoptera: Bruchidae) Hexapoda," vol. 15, pp. 64-66, 2008.

[30] S. Prabu Seenivasan, M. Jayakumar, N. Raja, and S. Ignacimuthu, "Efficacy of bitter apple (Citrullus colocynthis) seed extracts against pulse beetle, Callosobruchus maculatus Fab. (Coleoptera: Bruchidae),"Entomol. vol. 29, pp. 81-84, 2004.

[31] B. A. Annie, A. Babu, S. Ignacimuthu, and S. Dorn, "Efficacy of Andrographis peniculata Nees on Callosobruchus chinensis L. during post harvest storage of cowpea," Indian J. of Expl. Biol. vol. 39: pp. 715-718, 2001.

[32] N. Raja, A. Babu, S. Dorn, and S. Ignacimuthu, "Potential of plants for protecting stored pulses from Callosobruchus maculatus (Coleoptera: Bruchidae) infestation," Biol. Agric. and Hort. vol. 19, pp. 19-27, 2001. 